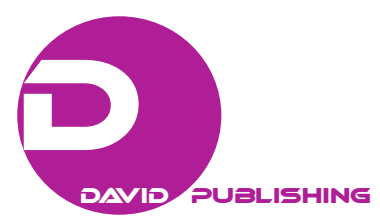

\title{
Vietnam Economic Situation and Its Impacts on Three Natural Resources: Air, Water, and Soil
}

\author{
Le Dieu Linh Nguyen \\ Hanoi University of Natural Resources and Environment, Hanoi, Vietnam
}

\begin{abstract}
The current economic development is the process of improving the physical and spiritual living conditions for people through the production of material wealth and the improvement of social relations as well as the improvement of cultural quality. In recent years, Vietnam showed robust growth in terms of economic development, along with the fast pace of urbanization and population increase. However, the economic growth has led to serious problems relating to the environment, such as the pollution of the air, water, and soil, which hugely affected the quality of human life. The Environmental Kuznets Curve (EKC) implied that a country with strong economic background shifting to industrialization or mechanization of agriculture will have positive GDP and the environmental damage level will decrease. The analysis and assessment showed that the environmental problems caused by economic activities are: air pollution in the urban area still maintained at high level; water pollution in rivers and limited fresh water supply; and the soil pollution and declining water supply underneath soil are developing.
\end{abstract}

Keywords: socio-economic development, EKC, air, water, soil, air pollution, water pollution, soil pollution

\section{Introduction}

After impressive results in 2018, Vietnam's economy continued to be strong in 2019. The fast growth of economic development nowadays led to an increasing need of natural resources, higher living quality, technology, and a healthy environment. According to the General Statistics Office, in 2019, the GDP's growth reached $6.79 \%$. Within the general growth, the industrial and construction sectors increased at $8.63 \%$-the highest rate amongst the sectors. The service sector and the agro-forestry-fisheries sector kept their momentum with upsurges of $6.5 \%$ and $2.68 \%$, respectively. It is expected that under the management of the government, this year's growth target at $6.6 \%-6.8 \%$ is still reachable.

Besides the positive results of Vietnam's economy, the environment is also facing many challenges and pressures due to the impact of economic market in the development process. This report will tackle the influences of economic development in Vietnam on the environment regarding three domains: air pollution, water pollution, and soil pollution, since they are the essential natural resources of future people.

Compared to renewable resources, non-renewable resources, such as metals, ores, petroleum, and gas do not need much land use to exploit. However, exploiting these resources can contaminate water resources, destroy the ecological environment, and create exhaustion that is no longer able to exploit for future

Le Dieu Linh Nguyen, M.Sc., lecturer, Faculty of Land Management, Hanoi University of Natural Resources and Environment, Hanoi, Vietnam.

Correspondence concerning this article should be addressed to Le Dieu Linh Nguyen, Hanoi University of Natural Resources and Environment, No. 41A Phu Dien Road, Bac Tu Liem District, Hanoi, Vietnam. 
generations. The impacts on the environment when exploiting natural resources is also reflected in the aspects of economic activities, such as energy and water consumption, depleting ecological environment in rivers and seabeds. Therefore, to limit the negative effects of resources, it is suggested that Vietnam needs to provide better policies for environmental impact assessment, environmental management, for efficient and sustainable exploitation.

Summary of findings is:

- The economy of Vietnam witnessed a massive growth in GDP and the foreign investment market has been more developing than before.

- Despite the success of economic growth in the past has produced many benefits, it also raised awareness of degradation of ecosystems and environment.

- Some environmental impacts are examined in the context of growth in economic activities, such as air pollution, water pollution, and soil pollution.

\section{Different Views on the Relationship Between the Economic Growth and the Environment}

There are various perspectives about the relationship of economic growth and the environment. According to the Environmental Kuznets Curve (EKC), the graph describes the relationship between the economic development and the environment's health. The vertical axis is considered as the damage level of environment, while the $\mathrm{X}$-axis describes the population income per capita.

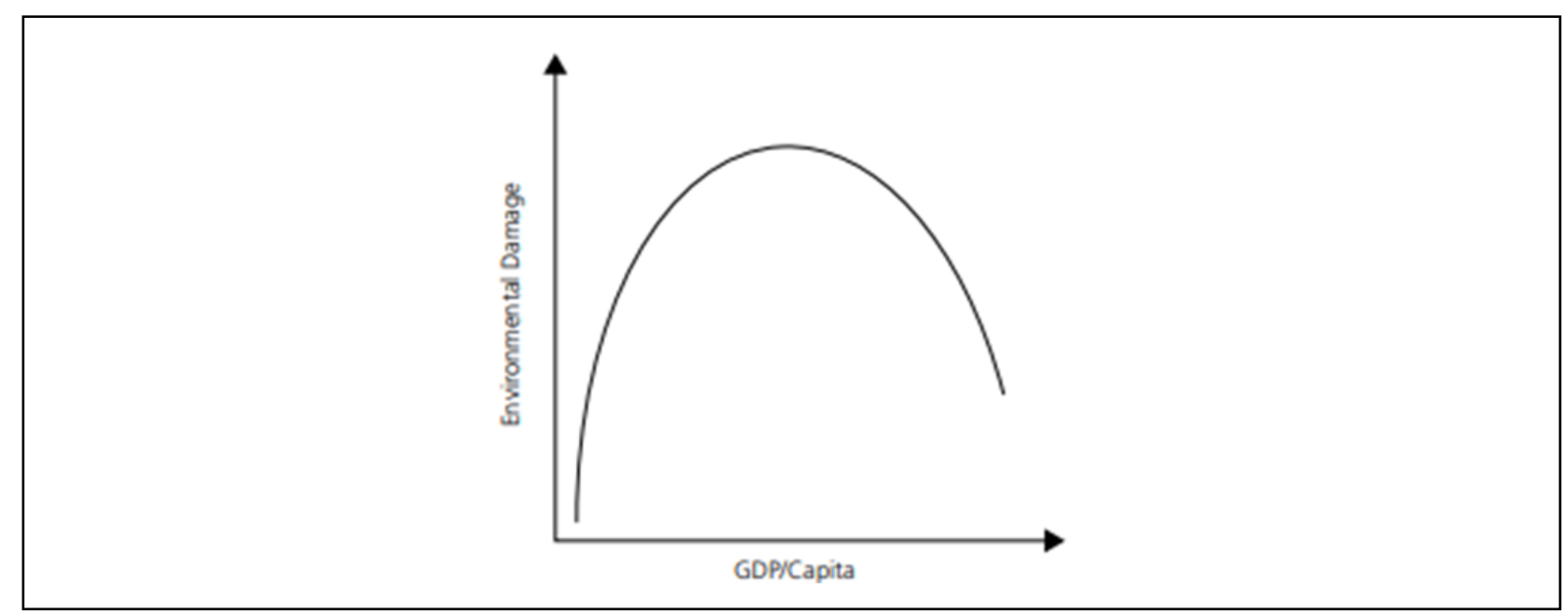

Figure 1. Environmental Kuznets Curve (Source: Economic Growth and the Environment, 2010).

In this theory, a country with strong economic background shifting to industrialization or mechanization of agriculture will have positive GDP and the environmental damage level will decrease. On the other hand, as at low GDP or negative GDP growth rate, the inequality is expected to increase.

There are other views on the economy-environment relationship. Arrow et al. (1996) said that small changes causing catastrophic damage focusing on the delivery from economic growth to environmental outcomes could be counter-productive, which is unlikely. For example, Dietz (2000) suggested that in the context of biodiversity, the increasing spending on maintaining species diversity will not be able to regenerate extinct species. Stern (2006) also pointed that the international competition could change the relationship between economic growth and the environment. The international competition could lead to increasing 
environmental damage, for example, developed countries start to bring their polluting activities, like moving industrial areas to developing countries. This model is called "race to the bottom".

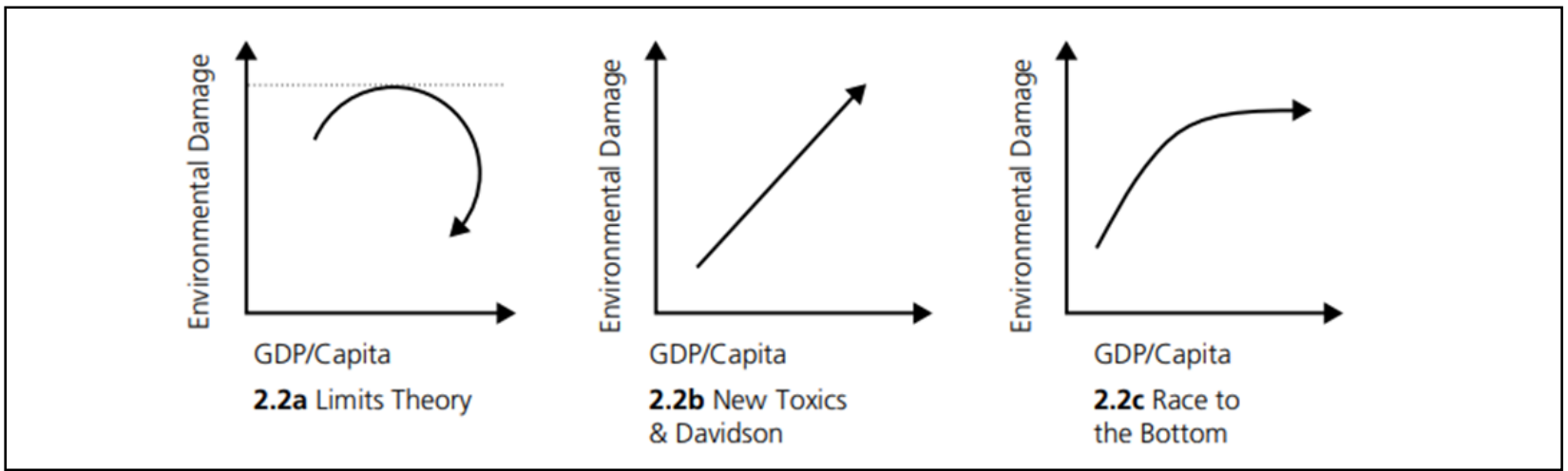

Figure 2. Different views on the economic growth and environment relationship (Source: Economic Growth and the Environment, 2010).

\section{Current Vietnam Economic Situation}

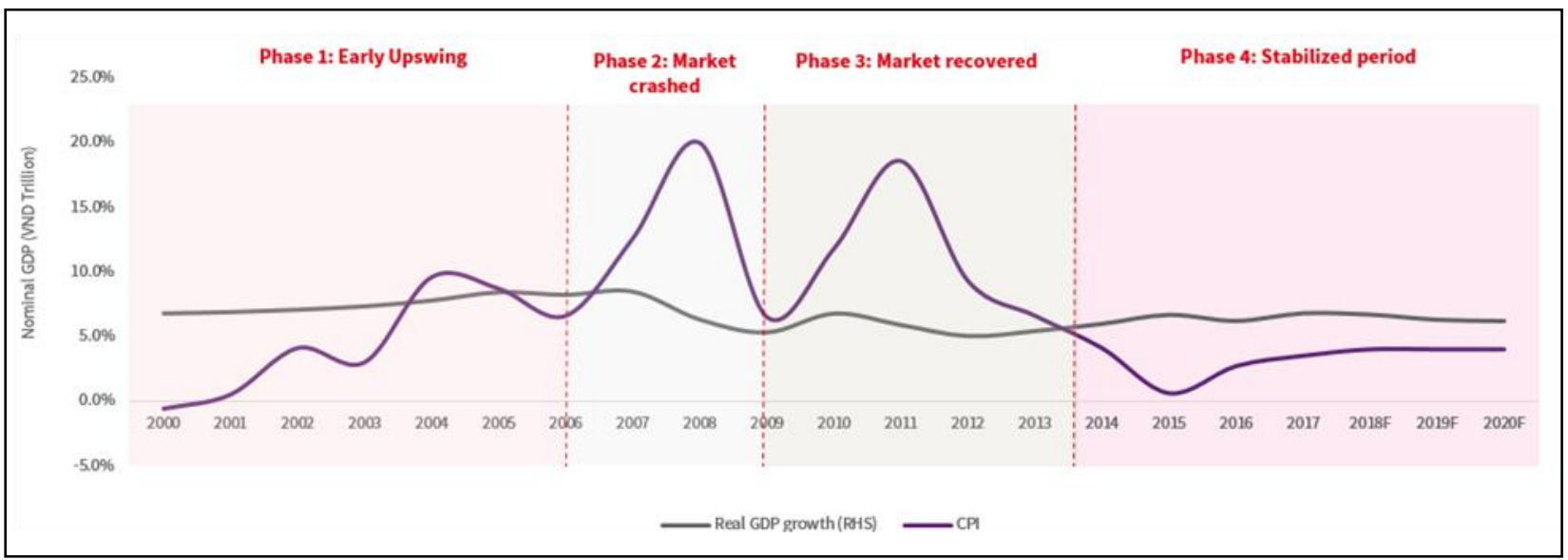

Figure 3. Economic cycle analysis (Source: GSO Vietnam).

From 2000 to present day, Vietnam's economy cycle can be divided into four stages as followings:

Phase 1: In 2000, Vietnam ratified the Bilateral Trade Agreement with the USA, marking a new age of the country's global economic integration. The expected accession of Vietnam to WTO helped to assure the positive market prospects over the period. During this phase, Vietnam welcomed a sizeable number of foreign direct investment (FDI) deals project, of that the majority of the FDI went into the real estate segment.

Phase 2: The stock market dropped from 1,200 to below 300 points, high inflation of nearly $20 \%$ in 2008, financial crisis led to the breakdown in the banking industry from 2008 to 2010. Similarly, the real estate market experienced the "bubble" in 2007-2009. GDP growth rate notably decreased in 2008 and 2009. On top of it, the base rate, as well as rediscounting rate and refinancing rate, hiked sharply in 2008 and 2009.

Phase 3: Government loosened its fiscal and monetary policies as a means to tackle economic issues from 2009 - tax incentives in the first half of 2009 helped buoy rally. GDP recovered in 2010, and interest rates decreased significantly. However, in 2011, interest rates/inflation increased to almost the level seen in 2008. Cause of too high inflation compared to target $(<7 \%)$ was due to the inevitable consequence of overextension 
of the money supply and credit growth in the previous stage and partly from the lack of proactive in operating monetary policy.

Phase 4: As of end-2015, the positive GDP growth rate reached $6.68 \%$ and this increase is expected to remain at $6.7 \%$ in 2017. Currency rate was also more stabilized in this period than in previous economic periods. Interest rates/inflation got the lowest level in a decade. In January 2016, ASEAN Economic Community (AEC) was officially formed, believed to highlight Vietnam's economy as well as other economies in the region.

Looking forward, the GDP in Vietnam is likely to remain flat by 2020 with positive growth rate. In the economic cycle life, the economic growth implies an increase in the amount of products and services through the development economic activities.

Whilst positive GDP reflects a healthy economy, the foreign direct investment (FDI) showed the interest level of enterprises or industry that present in the economy in the investment activities. According to Foreign Investment Agency (FIA) Vietnam, in 2018, regarding the 17 investment industries, processing and manufacturing sector continued its leading place, attracting USD 11.3 billion and accounting for $44.6 \%$ of total capital. The real estate and retail sector followed up in second and third place with USD 5.8 billion and USD 2.1 billion, respectively.

\section{The Impacts of Economic Development on the Environmental Changes}

\section{Air Pollution}

According to the General Statistics Office, in 2017, the number of population in Vietnam surpassed more than 93.7 million people, which increased by more than 4.5 million people. The increasing number of population, in tandem with the transportation, the construction, and industrial activities has triggered air pollution problems. In addition, the expansion and new set-up of industrial parks near the urban area also harm the environment, causing air pollution in urban areas. According to FIA Vietnam, the proportion of FDI pledged into the manufacturing accounting for $45 \%$ in 2018. In particular, there are about 283 industrial parks with more than $550,000 \mathrm{~m}^{3}$ of waste water per day and night. Most of polluted air from industrial parks are $\mathrm{NO}_{2}$, $\mathrm{SO}_{2}, \mathrm{CO}$, etc., of which the emissions, such as $\mathrm{NO}_{2}, \mathrm{SO}_{2}$, and total suspended particles (TSP) are largely contributed to the total polluted air.

\section{Water Pollution and Limited Fresh Water Supply}

Compared to the rapid urbanization in Vietnam, the water supply has not met demand of the population in the urban area. In 2016, the Ministry of Natural Resources and Environment announced that $40 \%$ of total water supply in urban area in each year is exploited from underneath the soil. Because of the overexploitation and unreasonable use of water supply, many urban cities in Vietnam is lacking water underneath the soil, such as Vinh Yen (Vinh Phuc), Hanoi, Ho Chi Minh, and Soc Trang.

Water pollution is a negative change of the physical and biological of water, with the appearance of substances in liquid and solid form that make the water become harmful to humans and creature. Considering the speed of spread and the scale of influence, water pollution is a more worrying issue than soil pollution.

\section{Soil Pollution}

The soil environmental quality in the urban cities are increasing polluted due to the outsource polluting from human activities. Currently, there are about $76 \%$ of industrial parks having waste treatment system and this polluted water absorbed in the soil. In 2015, the total area of landfill area is 12,260 ha, accounted for $0.3 \%$ 
of total area in non-industry land, increased 4,390 ha compared to 2010. However, the landfill area has not met the demand.

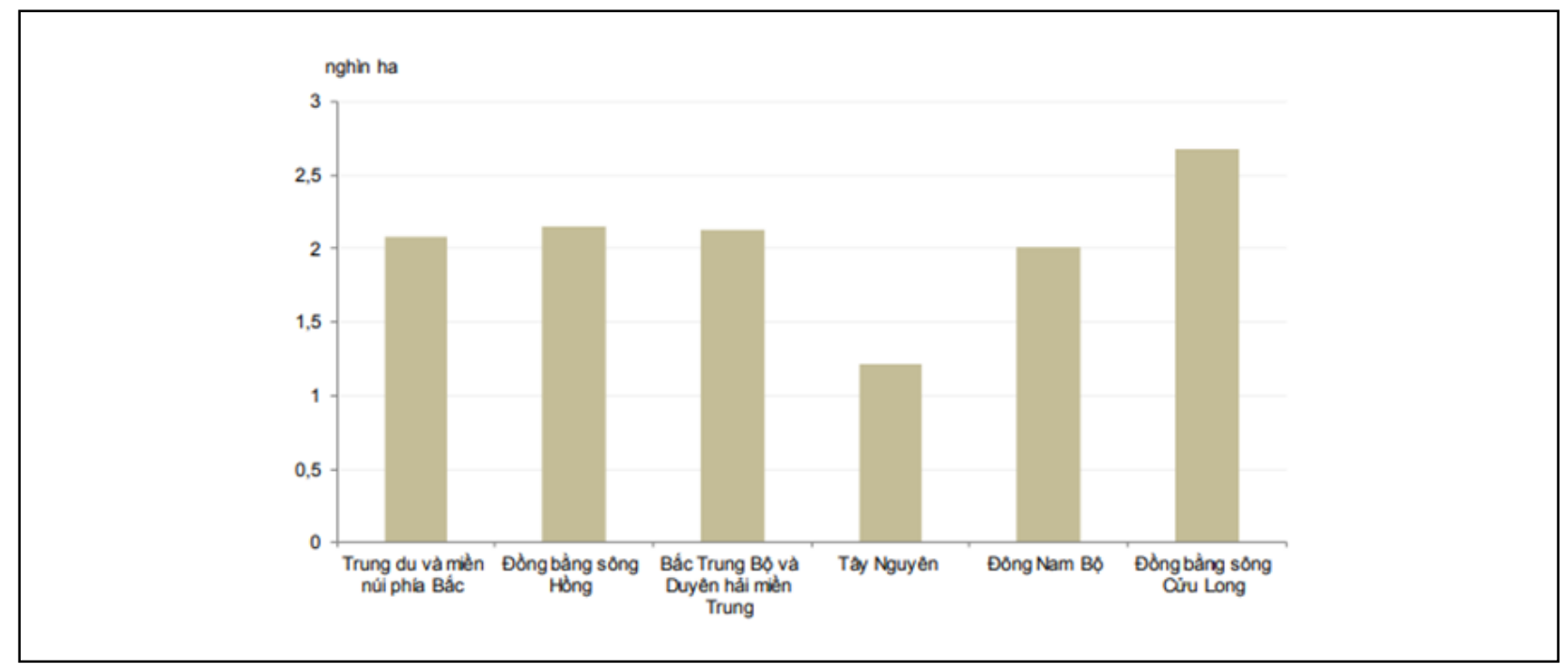

Figure 4. Landfill area in Vietnam by region (Source: Ministry of Natural Resources and Environment, 2015).

Soil environment in some urban areas is also affected by the activities of production and commercial construction, hospitals, medical facilities, etc. According to the Decision 64/2003/QĐ-TTg, there are 26 organizations causing serious environmental pollution. Most of them are textile, cement, chemistry, and oil industry, which are forced to leave urban areas of 13 provinces. In 2013, this number increased, with 34 organizations forced to leave 15 provinces or having solution to improve the environment.

\section{Conclusion}

Along with the fast pace of economic growth, the pressure from development activities puts pressure on urban areas in Vietnam. In terms of the economic analysis, Vietnam's economy in 2018 flourished with the GDP growth in 2018 reached $7.08 \%$ compared to 2017 - the highest increase in 11 years. The quality of growth and business environment has been improved, with newly established businesses increased sharply. The macroeconomic foundation is strengthened and gradually enhanced.

The report also provided some perspectives about the linkages between economic development and the environmental changes. The analysis showed that the GDP is a main contributor to the environmental damage and vice versa. Meanwhile, some other views pointed that economic growth to environmental outcomes could be counter-productive, or the international competition could lead to increasing environmental damage. However, different perspectives of the relationship between economic growth and environment supposed that the environmental changes are impacted by economic activities in line with the rapid growth of population and urbanization.

The analysis showed that the environmental problems caused by economic activities are: air pollution in the urban area still maintained at high level; water pollution in rivers and limited fresh water supply; and the soil pollution and declining water supply underneath soil are prevailing. The pollution in urban area not only impacts on human well-being, but also leads to the negative economic situation, environmental landscape, and environmental conflicts. 


\section{References}

Albrecht, J. (1998). Environmental costs and competitiveness: A product-specific test of the Porter hypothesis. Working Paper 98/50, University of Ghent, Belgium.

Ambec, S., \& Barla, P. (2005). Can environmental regulations be good for business? An assessment of the Porter hypothesis. Energy Studies Review, 14(2). Retrieved from https://energystudiesreview.ca/esr/article/download/493/471

Arrow K., Bolin B., Costanza R., Dasgupta P., Folke C., Holling C. S., Jansson B., Levin S., Maler K., Perrings C., \& D. Pimentel. (1996). Economic growth, carrying capacity, and the environment. Environment and Development Economics, 1, $104-110$.

Berman, E., \& Bui, L. (1998). Environmental regulation and labor demand: Evidence from the South Coast Air Basin. National Bureau of Economic Research Working Paper No.6299. Retrieved from https://www.nber.org/papers/w6299.pdf

Bimonte, S. (2009). Growth and environmental quality: Testing the double convergence hypothesis. Ecological Economics, 68, 2406-241.

BMI Research. (2018).Vietnam country risk report. Vietnam: BIM Research.

Carraco, C., De Cian, E., \& Tavoni, M. (2009). Human capital formation and global warming mitigation: Evidence from an integrated assessment model. Italia: CESIFO WP.

Choudhury, K., \& Jansen, L. (1997). Terminology for integrated resources planning and management. Rome, FAO, Soils $\begin{array}{lllll}\text { Resources } \quad \text { Management } & \text { Conservation. } & \text { Retrieved }\end{array}$ https://www.mpl.ird.fr/crea/taller-colombia/FAO/AGLL/pdfdocs/landglos.pdf

Costanza, R., \& Voinov, A. (1996). Interaction between economics and the environment from the point of view of sustainable development. In V. A. Koptyug and M. Uppenbrink (Eds.), Sustainable development of the Lake Baikal Region: A model territory for the world (pp. 33-58). Berlin: Springer.

Department for Business, Enterprise and Regulatory Reform. (2008). Material security: Ensuring resource availability for the UK Economy.UK: BERR.

Dietz S. (2000). Does an environment Kuznets curve exist for biodiversity? Insitut fur Wirtchaftsforschung, Eidgenossische Techische Hochschule Zurich.

General Environment Department. (2011-2015). Report, updated statistics of 3 national environmental indices: Air, water, sea water. Retrieved from http://tapchimoitruong.vn/pages/article.aspx?item=Báo-cáo-hiện-trạng-môi-trường-quốc-gia-giai-đoạn-2011---2015-42030

General Statistics Office. (2018). Socio-economic development in 2018. Vietnam: General Statistics Office.

Ministry of Natural Resources and Environment. (2016). National environmental situation 2016: Urban environment. Vietnam: Ministry of Natural Resources and Environment.

Stern, N. (2006). Stern review: The economics of climate change. Report for HMT. Retrieved from http://mudancasclimaticas.cptec.inpe.br/ rmclima/pdfs/destaques/sternreview_report_complete.pdf

Stevenson, B., \& Worlfers, J. (2008). Economic growth and subjective wellbeing: Re-assessing the Easterlin Paradox. NBER Working Paper No.14282. Retrieved from https://users.nber.org/ jwolfers/papers/EasterlinParadox.pdf

Stewart, R. B. (1993). Environmental regulation and international competitiveness. The Yale Law Journal, 102(8), $2039-2106$.

The World Bank. (2018). Vietnam economic development update. Retrieved from http://documents.worldbank.org/curated/en/119991529094262839/pdf/127168-VIETNAMESE-TakingStockVNfinal.pdf

Tim, E., Mallika, I., Ansaloni, G. P., \& Rubin, A. (2010). Economic growth and the environment. MPRA Paper No. 23585. Retrieved from https://mpra.ub.uni-muenchen.de/23585/1/economic-growth-environment.pdf $\begin{array}{llllll}\text { World Economic } & \text { Forum. } & (2013-2014) . \quad \text { Global competition } & \text { ranking. } & \text { Retrieved from } \\ \text { http://www3.weforum.org/docs/WEF_GlobalCompetitivenessReport_2013-14.pdf } & & \end{array}$ 